\title{
In Conversation with Mark Olssen
}

\author{
On Foucault with Marx and Hegel
}

Rille Raaper and Mark Olssen

\begin{abstract}
It is challenging to define who Michel Foucault was, whether he was a theorist, a philosopher, a historian, or a critic. In many of his books, and essays, Foucault denied being a philosopher or a theorist, nor did he want to be called a writer or a prophet. He described himself as an experimenter by saying that his work simply consists of "philosophical fragments put to work in a historical field of problems". Like Ball (2013, p. 2), we believe that Foucault tried hard not to be "a something", opening up opportunities to develop and practise theory. Emeritus Professor Mark Olssen has written widely on Foucault's theoretical underpinnings and legacy. This conversation aims to revisit Olssen's work, as well as Foucault's own writings in order to engage with Foucault's philosophical background and the methods he developed. By exploring Foucault's theoretical and methodological approaches, the conversation situates his work within broader traditions of social theory, particularly within the works of Marx and Hegel. Our conversation starts by discussing Foucault's relationship with Marx and Hegel and moves towards his approach to history and his wider contribution to the poststructuralist school of thought.
\end{abstract}

Rille Raaper: Foucault's transformative writing style is well known. Some Foucauldian scholars even differentiate between an early and late Foucault, pessimistic and optimistic Foucault among other similar contrasts. I have found these variations in his work fascinating. It seems that Foucault was also aware of his transformative style, if we can call it like that. He explained in one of his interviews that it was a desire to explore and understand the unknown that inspired his work: "I write a book only because I still don't know what to think about this thing I want so much to think about, so that the book transforms me and transforms what I think" (Foucault, 2002a, pp. 239-240). In other words, Foucault allowed himself to challenge and change his thinking over time. Perhaps one of the most important transformations in his work relates to his methodological shift from archaeology to genealogy. Foucault (1972, p. 154) explained archaeology as an approach that helps to resist the ideas of linear progression and

(C) R. RAAPER \& M. OLSSEN, 2017 | DOI: 10.1163/9789004464452_005

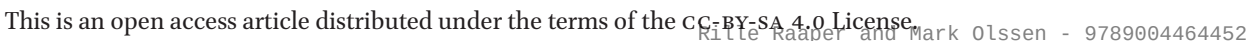


continuous history, and it enables the abandonment of the "history of ideas ... its postulates and procedures" to practise a "quite different history [to] what men have said". This means that archaeology focuses on processes as unique and discursive acts. Like archaeology, his genealogy was meant to function as a historical method but one that approached history from the perspective of discontinuity. It is not that society is just advancing and becoming a "better" place to live and work, but it repeats and disrupts itself. We will come back to his approach to history with one of my later questions. What interests me now, however, is Foucault's so called transformations. Foucault (1997b, p. 180) described his methodological shifts as "auto-critique". It was his "autocritique" that made it possible to shift from archaeology to genealogy. Furthermore, it was his "autocritique" that made him change his understanding of subjects as passively created by disciplinary power and normalisation - particularly evident in his writings on madness and penal systems - to individuals that have some agency over their own lives. His later work defined individuals as being controlled and constrained by someone else but also as being able to inform their own identity through conscience or selfknowledge (Foucault, 2002c). It looks to me that he managed to remain "true" to himself throughout his career. It was not just a fashion trend he followed, but it was something much bigger. How would you describe Foucault as a thinker and researcher?

Mark Olssen: I think Foucault is a towering thinker. It is pointless to seek to rank or be precise as to exactly where he stands in a rather large list of 2othcentury thinkers, but Foucault surely ranks as important, as does Deleuze, in reinterpreting Nietzsche, and Heidegger in a way that offered a new understanding of our most prized certainties, that incorporates them and underscores their importance for sociological and historical studies. It may seem strange to say this but he draws upon Nietzsche and Heidegger in a way that makes him more liberal than classical Western liberals at any rate. He finds teleology and vestiges of metaphysics not just in Hegel and Marx but in the standard Western liberal epistemologies and roads to truth, such as empiricism, and of course in that arch liberal, Kant, himself. In this, he agrees with and utilises Nietzsche, who finds in Kant too much metaphysics, especially concerning the foundational status of the subject, whose self-consciousness sits motionless and largely unaffected as history sweeps on past it. Such an anthropology of the subject underpins Kant's transcendentalism. It was this identification of a constant human subject, which depicts the subject as ahistorical, with an integral identity or "essence", that Foucault opposes under the umbrella of anthropological humanism. 
Rille Raaper: Can you explain a little further what Foucault means by humanism? It is obviously something that he perceives in relation to the Enlightenment episteme as we know from his essay "What Is Enlightenment?" (see Foucault, 1984). How does his perspective to humanism help us understand his work?

Mark Olssen: The critique of humanism is consistent throughout his work, and must be seen as having a very specific and limited scope, in the sense just stated. As Foucault explains, it envelops the subject in multiple senses:

By humanism I mean the totality of discourse through which western man is told: “Even though you don't exercise power, you can still be ruler. Better yet, the more you deny yourself the exercise of power, the more you submit to those in power, then the more this increases your sovereignty". Humanism invented a whole series of subjected sovereignties: the soul (ruling the body but subjected to God), consciousness (sovereign in a context of judgement, but subjected to the necessities of truth), the individual (a titular control of personal rights subjected to the laws of nature and society), basic freedom (sovereign within, but accepting the demands of an outside world and "aligned with destiny"). In short, humanism is everything in western civilisation that restricts the desire for power. ... [T] he theory of the subject is at the heart of humanism. (Foucault, 198od, p. 221)

Unfortunately, many liberal critics of Foucault have extrapolated and embellished the argument in a way that is simply intended to debunk and mystify. Foucault was well aware that humanism as a concept can take various forms, and can be seen exemplified in Christianity, Marxism, Existentialism, Phenomenology, Liberalism, even Nazism and Stalinism. Further, he appreciated that:

Humanism is ... a theme, or rather, a set of themes that have reappeared on several occasions over time, in European societies; these themes, always tied to value judgements, have obviously varied greatly in their content, as well as in the values they have preserved. ... From this we must not conclude that everything that has ever been linked with humanism is to be rejected, but that the humanistic thematic is itself too supple, too diverse, too inconsistent to serve as an axis for reflection. And it is a fact that, at least since the seventeenth century, what is called humanism has always been obliged to lean on certain conceptions of man 
borrowed from religion, science or politics. Humanism serves to colour and to justify the conceptions of man to which it is, after all, obliged to take recourse. (Foucault, 1984, p. 44)

In this Foucault follows Nietzsche who sees no constant, ahistorical, essence or nature that characterises man. Influenced by Nietzsche, too, Foucault utilises and extends the focus on language and interpretation to a formalised system of discourse where prized certainties piled up over time by science operate as forms of power which function as instruments of power and control, inclusion and exclusion. Such scientific discourses operate as new forms of biopower which increasingly pervade the various spaces of reason, truth, authority, and legitimacy, making the viewpoints or expressions of marginalised groups difficult to be heard or gain traction. As Foucault (1981, p. 52) says in "The Order of Discourse": "in every society the production of discourse is at once controlled, selected, organised, and redistributed by a certain number of procedures whose role is to ward off its powers and dangers. ... [T] he procedures of exclusion are well known". Foucault manifests a concern with the oppressive consequences of reason and science, seeking to expose its irrational underside. Like Nietzsche, in this sense, Foucault subjects Kant to a historical and sociological critique. For Foucault, the unresolved tension of Kant's philosophical project is that he fails to appreciate the contingent and historically contextualised character of all truth claims, that is to advocate a notion of critique which claims to transcend specific historical conditions through the exercise of cognitive faculties (of understanding, reason, and judgement) deduced a priori as timeless structures. In this sense, Foucault rejects Kant's claims to have established the universal grounds for the conditions of possibility of human knowledge, and Kant's claims for transcendental reason are replaced for Foucault by a principle of permanent contingency. Importantly here, Foucault is within the Kantian theatre, and effects similar criticism to those made of Kant by Hegel. By extension, Foucault disputes Kant's claim to have established a secure foundation by which to differentiate various types of knowledge claims, relating to science, practical reason, or aesthetics. The objective is to switch from a conception of critique which is transcendentally grounded to a conception of critiquehence, autocritique - which conceives it as practical and as historically specific.

I have found Foucault's life and academic career also fascinating. He was lucky enough in the end to be appointed to a high-status position in the Collège de France, where he had relative freedom to develop his research programme. As with many leading French academics, Foucault was also passionately political. This link between academic life and the world outside the university is one thing that defines the distinctiveness of the French intellectual. Foucault commented upon and was involved with many causes, but his work with prison 
reform was pivotal. With Deleuze, Foucault was one of the founders of the Groupe d'information sur les prisons, an organisation established to enable prisoners to argue for improved conditions. It is here that Foucault's concept of the "specific intellectual" took much inspiration. This notion contrasts with the idea of the "traditional intellectual", who speaks as a general and detached observer on behalf of mankind, and provides important context for understanding his relationship and detachment from Marx and Hegel. In his famous interview with Deleuze, titled "Intellectuals and Power", Foucault (1980a, pp. 207-208) notes that "the intellectual's role is no longer to place himself 'somewhat ahead and to the side' in order to express the stifled truth of the collectivity; rather it is to struggle against the forms of power that transform him into its object and instrument in the sphere of 'knowledge', 'truth', 'consciousness', and 'discourse'". In working practically, Foucault observes in the same interview, that

there exists a system of power which blocks, prohibits, and invalidates this discourse and this knowledge, a power not only to be found in the manifest authority of censorship, but one that profoundly and subtly penetrates an entire societal network. ... [I]ntellectuals are themselves agents of this system of power. (Foucault, 1980a, p. 207)

Rille Raaper: I like your description of Foucault as an academic with a clear societal contribution, whether it was his contribution to prison reform in France, the Iranian Revolution or involvement in other political events. We also know that he we was a member of the French Communist Party during the Cold Waryears. This obviously is a factual detail in Foucault's autobiography rather than significant political engagement. There has been a lot of discussion around Foucault's relationship with Marxism. I know that you have explored Foucault's critique of Marxism in your writings. For example, in one of your earlier articles, you have argued that Foucault's archaeological method allowed him to "challenge Marxism, which is concerned with a narrow linear conception of causality and enables him to advance a non-reductive and holist analysis of social life" (Olssen, 2003, p. 192). It is obviously clear that Foucault did not speak the language of the "dominant left"; he did not perceive the world in terms of ideology or economic oppression. The social world from a Foucauldian perspective is much more complex - power is not necessarily negative but can be productive even if sometimes risky or dangerous (Foucault, 2002d). We could therefore say that Foucault promoted a shift from traditional understandings of power in which power only presses on the subject from the outside (characteristic of Marxist views of power and oppression) towards an understanding of power as something that forms the subject by "providing the very condition of its existence and the trajectory of its desire" (Butler, 1997, p. 2): power is what subjects depend on for their existence. From a Foucauldian 
perspective we could all be our own oppressors and liberators. So tell me, even if there is a fundamental difference in the ways in which Foucault understands power and inequality, did Marxist ideology have any impact at all on Foucault's career and early stage work? How would you describe his relationship with Marx?

Mark Olssen: Foucault's thesis on the subjects of Marxism and totalitarianism were themselves relatively undeveloped, yet important. In my own work, I have sought to extrapolate Foucault's position on Marxism in relation to his express rejection of Hegel, his own more pluralist ontological position, as well as in relation to his scattered comments on Marx. I think also, his magazine articles, especially the one in Le nouvel observateur in 1977, were also insightful and effectively summarise his position. Foucault's endorsement of Glucksmann's “new philosophy'1 reciprocated Glucksmann's positive endorsement of Foucault's thesis, and his earlier suggestion that political theory should take a "Foucauldian turn" (see Glucksmann, 1975). Foucault's endorsement of Glucksmann's book signalled a number of important political and philosophical dimensions, even if only developed in embryonic form: first, a consistent antitotalitarianism as an essential feature of Foucault's own philosophical pluralism; second, a disillusionment with 1968 and post-1968 revolutionary politics as potentially totalitarian; and third, a chance to crystallise his rejection of Marxism, Marxism-Leninism, Stalinism, and Maoism, as political movements. Glucksmann had in an earlier work analysed Alexandr Solzhenitsyn's Gulag Archipelago as representing the culmination of Marxist historical dialectical development, ending up in the residue of totalitarian politics as expressed in the camps of Siberia, genocide and, by extension, Nazism (Glucksmann, 1975). As Foucault wrote in his review of Les maîtres penseurs:

Stalinism was the truth, "rather" naked, admittedly, of an entire political discourse which was that of Marx and of other thinkers before him. With the Gulag, one sees not the consequences of an unfortunate error but the effect of the most "true" theories in the order of politics. Those who hoped to save themselves by opposing Marx's real beard to Stalin's false nose are wasting their time. (Foucault, 1977a, p. 84)

Foucault, for his part, found sustenance in the anti-statist and pluralist discourses that characterised his own early works, focusing instead on the "micro powers" and "disciplines" that underpinned the state, and were prior to it. Marx is rejected, as is Hegel, as philosophers who totalise history and who represent the state as a legitimate organ of domination and truth. For Hegel it was philosophy that led to this totalisation through the reconciliation of opposites by which all contradictions were overcome. For Marx, it was the history of class 
struggles that achieved the same dialectical synthesis resulting in the communist utopia. These thinkers believe in "final solutions", "revolutionary goals and strategies", "the march of history", "dialectical progression", and identified power as emanating from a central agency in the state. Foucault agreed with Glucksmann's assessment that, influenced by thinkers such as Marx and Hegel, "[t]he Europe of states seeks to exclude the marginal" (Glucksmann, 1977, p. 119). Foucault's own alternative analysis denies any single location to power, representing it as a multiplicity of force relations across the entire social system in terms of which resistances are ubiquitous. By extension, class relations do not invariably determine power relations. This entails that there is no central agency of social change but rather a plurality of resistances and struggles against local fixations of power in specific sites.

Rille Raaper: Can you be more specific about the concept of totality to which Foucault objects?

Mark Olssen: The notion of totality is important here if one is to understand Foucault's relation to Hegel. Foucault's scepticism towards the idea of totality is developed forcefully in the "Introduction" to The Archaeology of Knowledge, where Foucault (1972, p. 10) distinguishes between "total history", which he opposes, and "general history" which characterises his own pluralist methodological approach, an approach which he says, "speaks of series, divisions, limits, differences of level, shifts, chronological specificities, particular forms of rehandling, possible types of relation". Although neither Marx nor Hegel is named in the text at this point, it is clear that Foucault is opposing a wellknown trend in historical philosophy associated with their writings. As he says:

The project of total history is one that seeks to reconstitute the overall form of a civilization, the principle — material or spiritual — of a society, the significance common to all the phenomena of a period, the law that accounts for their cohesion - what is called metaphysically the "face" of a period. ... [I]t is supposed that history itself may be articulated into great units-stages or phases-which contain within themselves their own principle of cohesion. (Foucault, 1972, p. 10)

The idea of society as an organic totality or whole had been an animating spiritual principle from ancient Greece through to the Middle Ages. The whole pertained to both the spiritual and physical order. Leibniz (1646-1716) had characterised society as a "pre-established harmony" in his Monadology based on the concept of the continuum; that the differences between things were differences of degree and were interconnected to the extent that "each simple 
substance has relations and express all the others, and consequently ... is a perpetual living mirror of the universe" (see Leibniz, 1898/1968, Section 78). At the start of the 19th century Hegel witnessed modernity as ravaged by crisis, division (Entzweiung), diremption (Trennung), and social atomism, effected by the rising bourgeois order, and the question he sought to answer was: How is it possible to salvage the idea of unity given such a situation? The question was important for Hegel as he appreciated that man is in most respects a product of his environment and a fragmented society (Bildung) would mean a fragmented subject, pertaining both to the individual and to community. Hegel's answer, which is also important for understanding Marx, was to historicise the notion. He sought to preserve the idea of a closed totality against the fragmenting forces of modernism by historicising it and injecting it with an overarching spiritual significance in relation to progressive development. ${ }^{2}$ Influenced by the experience of the French Revolution, as well as the philosophies of JeanJacques Rousseau ${ }^{3}$ and Sir James Steuart, ${ }^{4}$ Hegel claimed to detect a suprahistorical process of reason whereby such disintegrations were reconciled, preserving the unity of totality overall. Foucault (2005) comments in The Hermeneutics of the Subject that Hegel was characteristic of much of 19th-century thought (Schelling, Schopenhauer, Nietzsche, Husserl, and Heidegger) in linking knowledge to spirituality. John Grumley (1989) makes the point that this spiritual principle in important senses supersedes Kant and provides the major mechanism for preserving unity. ${ }^{5}$ As Grumley (1989, p. 18) puts it, "Hegel's surprising shift from Kant to Jesus in 'The Spirit of Christianity' represents a final rejection of Kantian moral asceticism". Society could maintain itself and prosper notwithstanding fragmentary forces of division and diremption through processes of reconciliation and regeneration built into life itself. Just as the body repairs itself from disease and injury, achieving repair and integration over time, so, too, can economy and society. Instances of violence and division are represented as but "moments" in a larger dialectical process of reconciliation and adjustment whereby the totality reintegrates itself at a higher spiritual level of development. For Hegel, such a process was both sociological, historical, and metaphysical, and applied to the individual, community, and society. The ravages of the rising bourgeois world were transcendable preserving unity as a progressive developmental spiritual process, culminating in the Absolute, Perfect knowledge, or God. It is fundamentally this spiritual/ teleological principle that Foucault finds objectionable and which is central to his own anti-totalising perspective. Closely linked to this is his rejection of dialectical method as a suprahistorical conception in terms of which historical change is schematically interpreted. As Foucault (1980c, pp. 114-115) told Alessandro Fontana and Pasquale Pasquino, dialectic constitutes "a way of evading 
the always open and hazardous reality of conflict by reducing it to a Hegelian skeleton".

Rille Raaper: In his own pluralist approach, which shuns totality, we can note that power, particularly a location of power, is a key concept in understanding how Foucault differed from Marx and Hegel. You also argue in one of your articles that it was Foucault's methodological focus on discourse that makes his work distinctive and helps us understand the complex relationship between Foucault and thinkers like Marx and Hegel (see Olssen, 2010). I remember you explaining that Foucault used his archaeological and genealogical methods - which are discursive methods-to challenge Marxism and its linear conception of causality and power that operates between the oppressor and oppressed (Olssen, 2003). It is obviously clear that social world for Foucault is much more complex, and like you said, he promoted a shift from singular power towards an understanding of power that operates in multiplicity and also allows multiple resistances. Based on a similar logic, Foucault perceived discourse as something more complex than just written and oral language. Foucault $(1981, p .67)$ argued that discourses should be considered as "discontinuous practices" which can be juxtaposed with each other but may exclude each other. It seems to me that his understanding of plurality in both discourse and power allows him to develop his distinctive approach to history. He was able to shift away from linear approach to historic events and to rather investigate "series, divisions, limits, differences of level, shifts, chronological specificities, particular forms of rehandling and possible types of relation" (Foucault, 1972, p. 11). Can we explore Foucault's approach to history a little further, and how does Foucault's understanding of history make him differ from other influential theorists, say Hegel?

Mark Olssen: The relation to Hegel and Marx, following Hegel, is of course central to understanding Foucault's methodology as well as his project as a whole. I have always emphasised this relation to Hegel by Foucault since my first book, Michel Foucault: Materialism and Education (see Olssen, 2006a). In a way, Foucault's entire approach reflects a conversation with Hegel. Another excellent more recent treatment appears by Gary Gutting, in his book, Thinking the Impossible: French Philosophy since 1960 (see Gutting, 2011), where he points out the central role of Hegel as the figure to which French philosophy for much of the 2oth century has responded.

Gutting (2011, p. 13) makes the point that "Foucault first came to full philosophical life when he encountered Jean Hyppolite". Hyppolite taught a course on Hegel's Phenomenology of Spirit at the Lycée Henri IV, where Foucault underwent his preparation for his entrance to the École Normale Supérieure 
(ENS) (Gutting, 2011, p. 13). He later sided with Nietzsche in opposing Hegel. Those aspects of Hegel he rejects are of course the senses in which Hegel is a philosopher of the Absolute, his Absolute Idealism and of dialectical necessity whereby contradictions are reconciled at progressively higher planes, resulting logically in Perfection. This is the sense in which Hegel seeks to integrate all phenomenological experience, that experience of the "unhappy" and "partial consciousness", as but moments in a progressive realisation of spirit's development through the historical process of dialectical synthesis, ultimately to a full unity in God. Foucault cannot abide Hegel's teleology, where conflicts, wars, evil, and famines are all necessary "moments" of a purposeful dialectic, resolvable at each higher level where their necessity and rationality also become apparent. Although opposed to Hegel in this sense, Foucault was deeply influenced by Hyppolite's reading of Hegel. This includes Hegel's focus on history and time, as well as his focus on historicity, language, and interpretation, rather than on mind. Foucault shared Hyppolite's concern to move away from the anthropological reading of the existentialists who emphasised human consciousness, moving instead towards a position where all experience is necessarily mediated by conceptual structures or discourses. If consciousness and mind are socially and historically constituted, then consciousness and lived experience themselves become subordinate to language and discourse. Hyppolite showed the path, says Foucault (1981, p. 74), "by which one can get away from Hegel".

For him the relation to Hegel was the site of an experiment, a confrontation from which he was never sure that philosophy would emerge victorious. He did not use the Hegelian system as a reassuring universe; he saw in it the extreme risk taken by philosophy. (Foucault, 1981, p. 74)

Foucault clearly credits Hyppolite, in the same way as Arkady Plotnitsky in his Foreword to Hyppolite's Hegel's Philosophy of History, as presenting a Nietzschean reading of Hegel (see Plotnitsky, 1996). Hyppolite concludes his thesis with the observation that:

There exists in [Hegel's] thought an ambiguity. That ambiguity is that the reconciliation of subjective spirit and objective spirit, the supreme synthesis of this system, is perhaps not completely realizable. (Hyppolite, 1996, p. 72)

Hyppolite's reading of Hegel is represented by Foucault as being deeply sceptical and sets Foucault on a trajectory which takes him outside of the Hegelian 
system altogether, while retaining some aspects of it. Foucault certainly sees Hyppolite if not as modifying Hegel in the direction of Nietzsche, then certainly as allowing Foucault to do so. As he says, "Instead of conceiving philosophy as the totality at least capable of thinking itself and grasping itself in the movement of the concept, Jean Hyppolite made it into a task without end set against an infinite horizon" (Foucault, 1971, p. 75). It is, continues Foucault,

[a] task without end and consequently as task forever recommenced. ... $[\mathrm{T}]$ he inaccessible thought of the totality was for Jean Hyppolite the most repeatable thing in the extreme irregularity of experience. ... He transformed the Hegelian theme of closure on to the consciousness of self into a theme of repetitive interrogation. (1971, p. 75)

For although the interest in obtaining absolute knowledge is rejected in Hegel, it is also the case that Foucault saw a similar concern as underpinning modernist thought in general, in that all major Western systems of knowledge saw truth as a slow upward pilgrimage towards greater and greater knowledge or truth. Notwithstanding all this, certain aspects of Hegel - the interest in historicity, mediation, language, culture, and history — are retained while being adapted. He was no doubt also aware of a certain non-foundationalism suggested by Hegel especially concerning notions such as truth, knowledge, ethics, culture and community could be retained while avoiding Hegel's overarching metaphysical system. ${ }^{6}$ Rather than Hegel's system, then, it was the sense in which he conceptualises history teleologically and totalistically that is rejected. Foucault regarded Hegel's philosophy as a closed system. Having studied with Hyppolite then, Foucault is very aware of how and in what senses his own philosophy departs from Hegel's.

Rille Raaper: So if Foucault rejected Hegel's Absolute Idealism and his way of doing philosophy, what was his influence on Foucault's approach to history?

Mark Olssen: Foucault is concerned not just with Hegel, but with something much bigger. He wants to avoid totalising approaches because they are teleological and closed. He is concerned very directly in his early writings on literature and on history with a new way of writing history, a way that constitutes what has become very definitely a new paradigm or a word I like better, a new settlement for how we understand knowledge of the world, a settlement which is both beyond Aristotle, and also Newton and Descartes. At the same time, Foucault appreciates the many ways in which he is close to Hegel. One thing both thinkers agree upon is their rejection of representationalist 
or correspondence theories of truth, the view that truth resides in a more or less direct correspondence between mind and world. For Hegel the attempt to resolve or overcome this impasse is via phenomenology and idealism whereas Foucault approaches the matter through genealogy. Because for Hegel there is nothing outside consciousness, the true cannot be independent of mind but projected by it. So development in the world is through a reconciliation of mind to world through successive conflicts (or reversals) of consciousness at progressively higher levels. It is in this sense that phenomenology is idealist for it sees the object in the world as part of consciousness itself.

For Foucault, the empiricist claim to the immediacy of knowledge is simply error. This is an argument he shares with Hegel, who argues against the immediacy of knowledge in The Phenomenology of Spirit of 1807. Foucault signals an affirmation and continuation of the linguistic turn by noting the ineradicability of the discursive through which every translation much proceed. This gives us the possibility of knowledge which is not simply that of truth, although it may contain truths, but is also simultaneously that of error and illusion. We could say that discourse exceeds the empirical content it organises. Every translation offers the possibility of falsehood, of distortion, of deception. The ghosts of past ages are carried forward with us and inhabit the lens through which we view the present. Rather than immediate, or direct, knowledge is a process of becoming. Although we may strive to understand the world rationally, our methods do not vouchsafe certitude or truth but rather may combine a mix of practical wisdom, reasoned truths, as well as folklore, superstition and falsehoods. How to distinguish good sense from folklore is crucial to offsetting relativism. Knowledge thus proceeds through perception, language, discourse, and comprises idols, ghosts and verities of ages past, alas all mixed up together, which makes the irrationalities of our present world, with its conflicts, wars, violence and divisions, and misunderstandings, at least understandable.

Rille Raaper: In other words, history as we know it is always biased and surrounded by falsehoods. We could even see the bias from the ways in which World War II is taught in different countries. It is the case of winners writing the history. So it is a very intriguing approach to history that Foucault was promoting, and I can see why he received and still receives quite a lot of opposition from historians. But if it diverges from Hegel and Marx, what else goes on here in Foucault's view of history? It cannot all come down to his opposition to empiricism and methodological focus on discourse?

Mark Olssen: No, there is far more than simply an opposition to classical empiricism and phenomenology and his development of the concept of discourse. 
Foucault is an empiricist, of sorts, too, of course, but not of the sort that Locke was. For Locke, the differences between things, although given as sensible qualities, are really differences in boundaries established by nature, and nature is presumed to be timeless and ahistorical, that is, a ground or foundation. Foucault would dispute such a naturalism, rejecting essential differences between things, asserting their interconnectedness, as well as their historical constitution. This view we might note is reminiscent of the early theorists of the continuum who dispute the "invincible solidity" of things or atoms. ${ }^{7}$ For Foucault, too, there is a different sort of relation between part and whole; each element expresses the whole, but there is clearly no universal principle of such expression, for there is no single rule that determines it in all times and places, which is to say that it expresses the whole or aspects of larger structures contingently, itself being affected by a multiplicity of variables. Diversity can be maintained because the ideal conception of "unity" is effectively replaced by a notion of "concord". At the same time, Foucault's empiricism avoids the dualism of mind and matter as bequeathed by Descartes, which for him was the disastrous bequest of the Enlightenment on modernity. Hence, the model of an isolated cogito, of the Cartesian individual, and of the mechanical universe, and of unity in diversity, are all rejected in preference for a new form of holism which rejects a whole conceived additively as the sum of its parts, as with Descartes, or as a comprehensive all-embracing collectivity, as with Hegel, and emphasises instead the contingent connectedness and dynamic interplay between part and whole. For Foucault, it seems to me, the idea of the isolated, ultimate part is as difficult as that of the comprehensive whole. Foucault would see his role here as rejecting metaphysical demons not previously evacuated by the thinkers of the Enlightenment: ideas of substance, of essences, of mind-body dualisms, of unified spirits, of the immediacy of sensory experience, and so on. So, of course, he is not certainly an empiricist as we usually understand that term, but nevertheless, he has for all that a healthy respect for the empirical adequacy of claims and stands opposed to the top down theoreticism he associates with Hegel and Marx.

Rille Raaper: What does this mean in terms of his methodological approach, genealogy in particular? I know he described genealogy as being "gray, meticulous, and patiently documentary", operating "on a field of entangled and confused parchments, on documents that have been scratched over and recopied many times" (Foucault, 1980b, p. 139). By working with a wide range of documentary evidence, he aimed to prove that humanity does not progress from "combat to combat" towards universal reciprocity but rather repeats its systems and mistakes (Foucault, 1980b, p. 151). I wonder if this is what you meant by interconnectedness 
and historical constitution in Foucault's approach to history. How would you explain Foucault's genealogy?

Mark Olssen: Foucault's genealogical empiricism was an empiricism of history and conflict where Foucault sought to chart histories based upon detailed archival investigations where he sought to avoid a dialectical account of historical change or of subsuming facts to an already established teleological system of the sort that Hegel developed. Foucault wanted a lesson from history which did not state it in advance but emerged as the outcome of history. In addition to this, he opposed the phenomenological view of the subject and consciousness as a foundation for history, preferring instead to give an account of the manner in which concepts rules, structures, and practices developed and changed over time. In this, while avoiding Hegel's overall system, he invoked many of the elements with which he was concerned and he saw in Hegel many ideas from which he profited. Yet, Foucault was interested in describing the way fundamental ideas pertaining to a society changed and for this he invoked Nietzsche and Heidegger against Hegel.

Foucault's approach to history also introduces a new model of determination as it operates in the world and introduces complexity themes of non-linear determination, uncertainty, non-predictability, novelty, uniqueness, and chance (aléa) into the historical process. He also rejects the model of machine replacing it with that of power (pouvoir, puissance, possibilitié, autorités, capacité, énergie, faculté, faire fonctionner, faire marcher, force). This is not necessarily to replace the metaphor of machine in all cases, but to supplement the model of machine with another model, and to see power rather than mechanism as what is central and all pervasive. Foucault did not deny the existence of linear relations of causality but was also aware that in many instances they were inappropriate. This constitutes a view of power as ubiquitous, and as productive as well as constraining, making Foucault's conception quite different from the Marxist tradition. Although he did not use the language of the quantum or post-quantum complexity theorist, nevertheless, in articles such as "Nietzsche, Genealogy, History" (see Foucault, 198ob), in his major books (see Foucault, 1972, 1977b), and in some of the lectures in Dits et écrits (see Foucault, 1994a, 1994b), Foucault seeks to analyse different sorts of determination, characterised by non-linear relations, feedback loops, and chance. Notice that this approach to history is also holistic, both ontologically and methodologically. It is not holistic in Hegel's or Marx's sense, of course, in reducing everything to a single foundation, nor in the sense of the Romantics, in positing the whole to the exclusion of the parts, but it does assert an ontology of interdependence of part and whole, and is, centrally, non-reductionist as well. Foucault announces 
a view of history which seeks to account for elements of individuality, novelty, uniqueness and freedom from a platform of historical constitution. It is in fact a new model of order based upon contingent and non-contingent relations, and where everything affects and implicates everything else. He sought in other words to establish an alternative model of history which remains open to both present and future and incorporates differences and otherness rather than seeking to homogenise or reconcile them. In relation to developments in science, his approach has resonances with quantum and post-quantum developments, of Planck, Heisenberg, Schödinger, Bohr, and Prigogine. It also confronted the dominant modernist view of science and knowledge, premised on predictability and certainty, with ideas of non-predictability, chance (aléa), uncertainty, the unforeseen, and unforeseeable.

Rille Raaper: You have written recently that Foucault developed much of this approach to history through his reading of literature. Can you say more on this?

Mark Olssen: I wrote an extended review essay of Michel Foucault's Language, Madness, and Desire: On Literature. Gary Gutting from Notre Dame asked me if I would do it. I also published a shorter version of this article as a book review in the Notre Dame Philosophical Reviews (see Olssen, 2016). My central task was to illuminate Foucault's core ontological and epistemological themes that developed in these early commentaries on literature and that were to inform the philosophical orientation of his social science investigations, including madness, psychiatry, medicine, the prison, sexuality, and the care of the self. The article suggests that Foucault's early works on literature establish a thesis of philosophical materialism which articulates many of the themes of postquantum complexity science as they affected the social and physical sciences in the late 2oth and 21st centuries.

Rille Raaper: This is very interesting. It also means that Foucault's relationship with literature was highly strategic, helping him to distinguish discursive practices from non-discursive practices. Can we then say that Foucault was searching for a non-Hegelian conception of history, something that would help to reject totality? Was this in your view central to Foucault?

Mark Olssen: What emerged from his readings of literature was a view of history which sought to preserve the uniqueness, or if you like, the distinctiveness of the individual in their individuality, uniqueness, novelty, and freedom, which giving up on preformed, ahistorical essences and substances, and seeing individuals as socially and historically constituted. What he was looking for 
was an alternative model of history, which remains open to both the present and the future, and which incorporates, but does not "homogenise" or "unify" difference and otherness, and which preserves also ideas of non-predictability, chance events, uncertainty, the unforeseen, and the unforeseeable. Here we can see there is already an early resistance to Hegel interpretation of history, based upon a dialectical unfolding and progression towards the Absolute. It is not surprising in that Nietzsche maintains the same argument against Hegel consistently across his writing career. ${ }^{8}$ We get the retention, of course, of the importance Hegel attributed to culture and the social, but the equation of the rational and the real, subject and object, and Hegel's notion of Geist, or Spirit, have completely gone. So has the dialectic both as an ontology and methodology. At the same time, he appreciated that Hegel is complex and difficult to escape, unless one goes completely the other way and accepts a classical atomism and individualism, where development is a result of internal essence or genetics, or soul, or whatever, and culture and the social are seen as purely derivative, secondary, non-efficacious and marginal. Post the development of quantum theory there is no possibility of going back in that direction. It is a dead end at any rate in a global interconnected world. What we need to do is confront those models of history that are presently on offer. And this means confronting Hegel. Hegel had a huge influence in Germany and on the Continent since the end of the 18th century and start of the 19th century, and a very large influence, too, from 1865 in Britain, when in political and social theory the British idealists became ascendant, until at least the turn of the century until they were knocked off their pedestal by Russell, Moore and the Logical Positivists. In France, too, the reception of Hegel has been variable and for most of the 2oth century they have been trying to escape him. Foucault appreciates, however, that this is no easy matter. As he said in his inaugural lecture at the Collège de France:

I know ... our age, whether through logic or epistemology, whether through Marx or through Nietzsche, is attempting to flee Hegel. ... But to truly escape Hegel involves an exact appreciation of the price we have to pay to detach ourselves from him. It assumes that we are aware of the extent to which Hegel, insidiously perhaps, is close to us; it implies a knowledge, in that which permits us to think against Hegel, of that which remains Hegelian. (Foucault, 1972, p. 235) ${ }^{9}$

This is a very interesting statement. In recent quantum and post-quantum complexity approaches to the social sciences, Hegel's representation of Sittlichkeit, or ethical life, as a general relational form of community, which stresses the 
social and historical constitution of individuals is clearly still present. It is not that the genetic is entirely discounted in such a view, but that it is seen as only one of many factors, in theory, of an infinite list of factors, that affect development. It is surprising how this view which gives a central role to nurture and to causal indeterminacy is now increasingly accepted in approaches such as epigenetics. ${ }^{10}$ Also, now, Hegel's teleological dialectic is recast and translated into a protoperformativist view whereby the future must be consciously created in the light of the limited and fallible knowledge that we retain in the present. But what is gone is what was problematic in Hegel, such as the unity of reason and history, where Hegel would assert that whatever was real was rational. There is a passage in a paper by Suzanne Gearhart, which states:

Whereas Hegel stresses that reason and history are one, Foucault seeks to write a history of madness; whereas Hegel seeks to guarantee historical continuity, through a dialectical process that links opposing and discontinuous terms, Foucault attempts to break with the various forms of historical continuity, and in particular the historical narrative. Whereas Hegel writes the history of the subject, Foucault focuses his "histories" on themes that reveal the precarious - or in any case the derivative — status of the subject. (1992, p. 58)

Rille Raaper: Can we then say that Foucault's desire to find an alternative model of history is actually about finding a new way to explain social reality?

Mark Olssen: Whereas Hegel unifies subject and object in the Absolute Spirit via successive reconciliations, Foucault rejects the dialectic in favour of an ontology of differences, and of the ultimate irreconcilability of discourse and practice. Foucault most emphatically objected to the idea of dialectical progression as well as the equation of the real and the rational. At one important level Foucault took this as to mean that there was an equivalence between perfected thought, and scientific observation, and reality itself. In their different ways, this was the dream of rationalism, positivism, empiricism, and phenomenology. Did not all of these advocates declare that there was no distinction between thought and reality, between ideas or words and things? Did they not all, like Hegel, declare there to be no such world of ideas separate from reality, which required relating to reality? Hegel, along with many others, thought that discourse, ideas, thought, what have you, was all of a piece. Russell criticised the British Hegelians for this, referring to it as panlogicism. For Foucault, similarly, reality always needed interpreting, not so much by thought, which is very idealist, and subjective, but by discourses, which are themselves historically 
constituted, and material. Unless we define it thus, we misunderstand the processes and nature of understanding as opposed to existence. To conflate them, or to dispense with discourse as not being an obstacle to true knowledge, is to make a serious error. Moreover, while established discourses permit some sort of correspondence with truth through careful triangulation in history, such truths are never easily maintained; they are never vouchsafe, and may often be paired with phantoms, idols, ideologies, and ghosts, which may distort them, or mislead.

Rille Raaper: It clearly appears that it is the concept of discourse that reveals Foucault's understanding of reality and truth. In your very recent review paper, you described Foucault's work as constructivist (see Olssen, 2016). Correct me if I am wrong, but is not constructivism rooted in phenomenology and hermeneutics, shaped by the earlier works of Edmund Husserl on phenomenology as well as by German philosophers on hermeneutics. I suppose you understand why I am curious aboutyour statement. Would you explain how does constructivism align with Foucault's work on discourse? Can you elaborate on that?

Mark Olssen: A great deal of confusion has developed over the concept of constructivism. Many writers, especially feminists like Butler (1990), Haraway (1991), and Barad (2007), have all criticised use of the concept. Barad (2007, pp. 32, 90, 134-137) uses the concept of "proto-performativity" rather than constructivism and claims that the latter elevates the linguistic or the discursive over the material. I think the argument is trivial and pedantic in most respects in that words can mean anything you like, as Alice said, in Wonderland. It has been also rather confusing. Initially I stopped using the word "constructionism" because of its association with idealistic ontologies, that is, that discourse constitutes the things of which it speaks. I intended constructivism to avoid such idealistic connotations by representing discourse as a way of organising or representing practices, by referring to its constructive aspect on the grounds that practices or world cannot be represented except through discourse. This is clearly more in the sense that Foucault intended it notwithstanding that some of his own phraseology contributed to the confusions in question.

Clearly the problems that Barad identifies as being associated with constructivism are indeed problems, if indeed one commits the sins she associates with the concept, and likewise that Butler (1990, pp. 109-114) and others associate with the concept, but my use of the term constructivism does not commit any of these fallacies. In my use of the concept, constructivism does a number of things: firstly, pertaining to an epistemological sense, it refers to the discursive construction of meaning and it challenges the representationalist claim 
that we have unmediated access to the real, or that language can faithfully and unproblematically represent the world as it really is independent of historically constituted discourse. In this sense, discourse is a way of organising practices. Although constructivism is social and historical, I also do not intend that discourse constructs the objects of which it speaks except in the sense that it always adds an interpretative context. This needs specifically pointing out as the phrase "discourse constructs the objects of which it speaks" is one Foucault used in one particular work to convey the constructive aspect of discourse. But as it becomes abundantly clear in The Archaeology of Knowledge, and the major works of the 1970s, although discourse maintains a constructive role, this does not deny that there is something there outside of discourse, a something Foucault refers to as the "non-discursive" that is independent of discourse (1972, p. 68). What it does suggest though is that discourse nevertheless adds something to representation. Any framing of reality will comprise multiple elements and may be more or less faithful to whatever is there independent of discourse. But it will also frame it in a particular way and comprise aspects of ideology from past ages. However reality is represented will reflect the paradigmatic assumptions of the age in terms of its ways of seeing and believing. It will include elements of good sense, based on truth, as well as elements of folklore and superstition. Hence, constructivism opposes crude representationism; it refers to the fact that our methods and representations are not simply unmediated representations of the world.

Secondly, pertaining to normativity, I am also referring to constructivism in an ethical sense as a task or challenge for humanity. In this sense, it is opposed to teleology and naturalism. This is the sense in which there is no pre-ordained telos, divine purposes, fate, or ends of man, or constant, ahistorical or timeless nature. Constructivism therefore stands opposed to Aristotle's essentialism which states that man seeks to fulfil his nature, as if the essence of being unravels through time. It stands opposed to all views of nature as timeless and ahistorical. Constructivism, therefore, signals that creating the future is an infinitely open endeavour on the basis of a past already provided, replete with uncertainty and danger, and can only be imposed by living beings. It will comprise numerous false starts, blind alleys, and wrong turnings. I always think it makes sense of Foucault's comment that "everything is dangerous".

So, despite a rather unnecessary fanfare over the issue, ultimately it does not matter which concept one uses so long as one does not commit the fallacies that $\operatorname{Barad}(2007$, pp. 43, 133) detects. If those utilising the concept of construction have committed these, then they are in error. It is equally true that those using the concept of "proto-performativity", Barad's favoured term of expression, are equally in danger of accepting the "misconception that would equate 
performativity with a form of linguistic monism that takes language to be the stuff of reality", as Barad (2007, p. 133) herself notes. So we can all concur that a naïve form of anti-realism that sees the world of things as the product of language is not the thesis that is being advanced.

Rille Raaper: Can we consider Foucault as being constructivist also in terms of science and scientific knowledge?

Mark Olssen: Yes, Foucault is also a constructivist as regards scientific knowledge. Again, this does not entail that Foucault believes that the world is constructed through discourse, or that empirical adequacy is not important, or relevant, to knowledge. I think that methods of cross-referencing or triangulation can provide some basis for epistemological warrantability. At the same time, it is no use trying to insist that empirical adequacy contradicts or counters constructivism, or that it constitutes evidence of realism. The issues at stake are far more complex. Foucault is not, also, denying the existence of a mind or discourse or human independent world, nor is he denying that human independent facts are important constraints on the development of knowledge. What he is denying is that our perspectives of the world, generated through language and discourse, constitute in any sense, a "mirror of nature", in any simple or straightforward sense. Having said that, they are not straightforwardly either, mirrors of society or culture or power as wielded in history. Such views of constructivism are simply an oversimplification and generate simplistic confusions. As an epistemological issue, constructivism signals that discourse is not solely a vehicle for representing true knowledge, or reason, but contains also within the discursive framework of representation, various, let us say, non-epistemological factors - idols, ghosts, superstitions, ideologies, and distortions - that are carried along with it; that are generated within history, and which serve, in different ways, at different times, to distort, obfuscate, slant, warp, structure, or qualify, the epistemological returns of knowledge generation. In this sense, constructivism is a shaking free from Descartes dualist postulations about knowledge or science, mind and world. Science, of course, seeks to be systematic and objective, and sometimes it may be, but witness the many false starts, wrong turnings, reversals, setbacks, errors, and deceptive announcements.

Rille Raaper: Isn't this an unacceptable scepticism? Is there any way to distinguish the idols or superstitions that inextricably accompany knowledge in order to gain reliable knowledge, in an epistemological sense, or are we forever with Foucault stuck deep in a quagmire of relativism? 
Mark Olssen: Foucault was well aware of this issue, of course, and Habermas and others levelled this charge at him. The very fact that power is always associated with knowledge raises the question as to warrantability for reliable knowledge. It raises serious problems such as how does one know if something is genuine knowledge or not, which cannot be fully gone into here. What can be said is two things: firstly, Foucault raises the matter of the difficulty of assessing reliable knowledge in the light of the fact that power is inextricably mixed up with it, and this is a difficulty which does indeed confront us in history, where the search for knowledge is full of errors, deceptions, false starts, wrong turnings, outright fraud, and other embarrassments. Secondly, Foucault's writings warn us as to our arrogance, or perhaps the arrogance of modernism, in believing naively in progress and infallibility, while failing to see the irrational underside of science and reason, with respect to nuclear power, climate change, environmental degradation, death, war, and destruction, that modernist science has unleashed. Given these issues, Foucault's insights invite circumspection, reflection, cautiousness, and humility—and these in themselves are not bad things. As to how relativism can be overcome, Foucault never really got round to addressing the problem. But given the difficulties of reliable knowledge, surely some tentative confidence can be gained through "cross-checking", "triangulation", "repetitions over time", within and between discourses and practices. The fact that science can achieve results, like putting a person on the moon, or curing a disease, would seem to inspire some confidence, tentative and cautious although we perhaps should be.

Rille Raaper: If Foucault agreed with the existence of an independent reality, should not we say that he was a realist rather than a constructivist? For example, Al-Amoudi (2007) argues that while Foucault uses a vocabulary that is different from critical realist vocabulary, he still promotes a similar understanding of reality as the realist, Roy Baskhar, would do. Al-Amoudi (2007) explains that Foucault promotes a relational conception of society, while recognising that people's actions and social relations exist in two groups of mechanisms that are ontologically distinct: so-called strata of tactics/individuals and strategies/society. I wonder whether the two - critical realism and constructivism - are actually more alike than we usually think. What are your thoughts on it?

Mark Olssen: Whereas the ontological fabric of reality is for the realist a matter of transparent discovery via a neutral method, for Foucault, discourse maintains an autonomous and constructive or dynamic relation to the world which means that it scars, it distorts, it conceals, and adds to or embellishes, 
simultaneous with any positive knowledge it generates. For Foucault, too, the being of the world is not discovered, but constructs in a further sense, in that it projects categories and frameworks; it sorts in historically variable ways. There is "instability of boundaries" by which objects are defined and which they can be defined as constituting some sort of a "natural kind". The problem for Foucault, I think, was not so much an issue with "nature", as an ontological existent, as such, but with the traditional postulations about nature which represented it as timeless and ahistorical, as some sort of "cosmological constant", to use Einstein's concept, as a benchmark which could ground objectivity and truth. Foucault utilises Barthes theory of semiotics to question any pre-established harmony between signifier and signified and focuses instead upon the role of language and discourse in establishing referentiality. I believe, though, that the sense in which Foucault was a constructivist was much more cautious than you read in Anglo-American philosophical critiques and the like, where constructivism is simply translated to refer to a fairly crass type of antirealism. Foucault had the knack of creating the impression that he was much more extreme than he in fact was. I think for Foucault, that by accepting the cultural specificity and the role of extra-epistemological factors in discourse construction we do not have to completely give up on constructing theories that are adequate representations of an independent reality. Discourses of science put down stakes into the world; they "intervene" or "experiment". Ian Hacking's book, Representing and Intervening (see Hacking, 1982), marks a contribution here. Nietzsche's focus upon "experimentation" is perhaps also important. Hence, Foucault is saying that a theory, or discourse, may have access to the ontology of being of the world in the sense of being able to give a more or less adequate account of it, in terms of controlling it. What it cannot do, however, is claim to give an actual literal description of our world, or claim that representations "represent" an independent reality "without remainder", establishing objectivity and truth for all time. Foucault is, as I have pointed out before, a moderate constructivist in that he stands opposed to naïve traditional forms of representationalism. This has of course now been pointed out by many, including Butler, Haraway, Barad, and others, as already referred to. I like the point that Barad (2007, p. 48) makes, attributed to Joseph Rouse (1996) concerning the deep similarities between realists and constructivists, instead of always representing each other as maintaining "bizarre" and "far-fetched" antithetical positions. To summarise it, both groups see knowledge as mediating access to the material world which is there independently of humans, and other life forms. "Where they differ", says Barad (2007, p. 48), "is on the question of the 'referent". Realists, however, see representations as being of things as they "really are" in a way that is both "timeless" and "ahistorical", whereas constructivists allow for a much greater role for culture, history, and language, 
and see representations as an admixture of both epistemological and extraepistemological factors, the latter which may comprise various paradigmatic axioms concerning such matters as the conceptions of human agency, the role and existence of genetics, the respective weight put on nature or nurture, and so on. It is these factors which mean that representations are not likely to constitute an unproblematic, straightforward, or unmediated copy of a mind or human independent world.

Rille Raaper: To conclude our conversation, let's explore Foucault's legacy a little further, particularly his contribution to poststructuralist school of thought as we understand it today. You have argued that you would align Foucault with poststructuralism, particularly of materialist tradition (see Olssen, 2010, 2006a; Olssen, Codd, \& O'Neill, 2004). It is obviously clear that Foucault (1997a, p. 131) described his work as situated "at the intersection of different currents and different problems". He described those "currents" and "problems" as placed in phenomenology, Marxism and the history of sciences (1997a, p. 131). We also know that he tried to escape these dominant forces by studying Nietzsche, opposing Hegel and Marx, and aligning with thinkers such as Georges Bataille, Maurice Blanchot, Pierre Klossowski (Foucault, 2002a). Those scholars invited him to question "the category of the subject, its supremacy, its foundational function" (Foucault, 2002a, p. 247) and allowed him to develop the practice of desubjectivation: the process that Foucault described as "wrenching the subject from itself, of seeing to it that the subject is no longer itself, or that it is brought to its annihilation or its dissolution" (2002a, 241). This view of the subject, as well as his approach to history and reality as discussed earlier, is something we often associate with poststructuralism. To summarise our conversation, can you reflect on Foucault's role in poststructuralist school of thought? I mean, how did his readings shape his work and perhaps also his belonging to the new way of practising history, science and philosophy?

Mark Olssen: It was through a very broad reading of literature in the library of the École Normale Supérieure that Foucault "deconstructed an order of discourse". The editors of Foucault's Language, Madness, and Desire: On Literature (see Artièries et al., 2015), cite Daniel Defert (2001) who fills in some of the detail of Foucault's engagement. We are told that Foucault read:

Saint-John Perse in 1950, Kafka in 1951, Bataille and Blanchot in 1953, followed by the progress of the nouveau roman (including the work of Alain Robbe-Grillet), discovered Raymond Roussel in the summer of 1957, the authors associated with Tel Quel (Philippe Sollers, Claude Ollier) in 1963, reread Becket in January 1968. (Artièries et al., 2015, p. VIII) 
During his travels, to Uppsala and Warsaw in the 1950s, Foucault both read literature and taught courses, from his favourite poet at the time, René Char, and from Sade to Genet.

The relationship with literature constitutes a testimony to understanding the way Foucault's philosophical mindset developed. Many of the literary gestures, insights and motifs from his early reading are incorporated within his great works in the sense that they generate philosophical axioms about general ontology and epistemology which remained central to his own philosophical project. Foucault utilises various forms of literature (narratives, epics, poetry, comedies, etc.) to demonstrate and inform his archaeological conception of discourse in relation to all number of philosophical concerns. Literature, in Foucault's hands, helps establish the manner and substance of his major arguments with respect to ontology and epistemology. On the one hand, it furthers the archaeological project in order to enquire into the distinctiveness of the literary discourse and position it in the field of discourses. On the other hand, Foucault is also saying that ideas float freely from one field or discourse to another and the thesis that such ontologies are purely a result of linear accretions of research in the domain of science are highly improbable. The ontological thesis that Foucault develops is one of radical linguistic or discursive indeterminacy by which any one translation can always be replaced by another, and which establishes the autonomy of discourse from the real is a thesis shaped by Foucault's early readings of literature. While he read, however, he was searching for the solution to deeper problems and topics. On its own, of course, he made clear in his book on Raymond Roussel, ${ }^{11}$ literature has no specificity or strategic centrality. The thesis of the literary then turns out to be the thesis of discourse as autonomous, strategic, and constitutive which escapes empiricist formulations of representation as well as correspondence theories of the real which see the real as accurately and completely revealed through discourse. Literature is central to the development of his distinctive philosophical thesis although it sits somewhat uncomfortably with his shift to a more materialist position after 1968, I believe he retained this thesis. For Foucault the literary generates conceptions of indeterminateness, novelty, chance, unpredictability, and multiplicity of the meanings in relation to the real. His reading of literature thus solved puzzles and generated ideas, which he later on puts into play with his social science studies. Literature also opposes established and settled meanings; it deconstructs established hegemonies. It is this ontology of complex determination, developed initially by Foucault in the early 196os, that he essentially counterpoises to Marx and Hegel. 


\section{Acknowledgement}

This chapter originally appeared as Raaper, R., \& Olssen, M. (2017), In conversation with Mark Olssen: On Foucault with Marx and Hegel, Open Review of Educational Research, 4(1), 96-117, http://dx.doi.org/10.108o/23265507.2017.1334575. Reprinted here, with minor edits, with permission from the publisher.

\section{Notes}

1 Translated by Michael Scott Christofferson, the article is reproduced under the title of "The Great Rage of Facts", in Zamora and Behrent (2016, pp. 170-175).

2 See, for instance, the "Preface" to the Phenomenology of Spirit (1807), where Hegel says: "The truth is the whole".

3 Hegel was impressed initially both by Rousseau's ideas of democracy as well as his thesis concerning the disintegration of society under the force of economic and social developments.

4 See Plant (1973). Plant argues that in his An Enquiry into the Principles of Political Economy (1767), Steuart develops a progressive, evolutionist approach to political economy. The thesis is included in Hegel's early essay "The Spirit of Christianity and Its Fate" (1798-180o); see Hegel (1948).

5 See Hegel (1948). I am indebted to John E. Grumley for his excellent discussion of the importance of religion in Hegel's early writings; see Grumley (1989).

6 The view that Hegel's philosophy can be interpreted to represent truth and knowledge in distinctively non-foundationalist and non-metaphysical terms has been suggested by many thinkers, for instance, in recent decades, Hartmann (1972), Rose (1981), Houlgate (1986), Maker (1994), Sallis (1995), Hutchings (2003) to name but some.

7 Such a view is found in Leibniz for instance, in both: Leibniz (1898/1968, Sections 8, 10, 16, 56-58, 61); and Leibniz (1898/20o9, Sections 1, 2, 4). The phrase "invincible solidity" is from Leibniz, cited in Stark (1943).

8 See, for instance, the early essay, "On the Uses and Disadvantages of History for Life" (Nietzsche, 1997).

9 Foucault had earlier expressed this view in his eulogy to Hyppolite in French at the École Normale, published in 1969 in the Revue de Métaphysique et de Morale. See Canguilhem and Foucault (1969). The lecture was also presented at the Collège de France, 2 December 1970, and was appended, under the title "the discourse on language to the archaeology of knowledge".

10 Epigenetics asserts that environment is crucial in switching genetic predispositions on or off; see Carey (2012).

11 Published in English as Death and the Labyrinth in 1986; see Foucault (1986).

\section{References}

Al-Amoudi, I. (2007). Redrawing Foucault's social ontology. Organization, 14(4), 543563. https://doi.org/10.1177/1350508407078052 
Artièries, P., Bert, J.-F., Potte-Bonneville, M., \& Revel, J. (2015). Editors' introduction. In M. Foucault (Ed.), Language, madness, and desire: On literature (P. Artièries, J.-F. Bert, M. Potte-Bonneville, \& J. Revel, Eds.; R. Bononno, Trans.; pp. 7-16). University of Minnesota Press.

Ball, S. J. (2013). Foucault, power, and education. Routledge.

Barad, K. (2007). Meeting the universe half way: Quantum physics and the entanglement of matter and meaning. Duke University Press.

Butler, J. (1990). Gender trouble: Feminism and the subversion of identity. Routledge.

Butler, J. (1997). The psychic life of power: Theories in subjection. Stanford University Press.

Canguilhem, G., \& Foucault, M. (1969). Jean Hyppolite (1907-1968). Revue de Métaphysique et de Morale, 74(2), 129-136.

Carey, N. (2012). The epigenetics revolution. Icon Books.

Defert, D. (2001). Chronologie. In D. Defert \& F. Ewald (Eds.), Dits et écrits, vol. 1, 19541975 (pp. 13-9o). Quarto/Gallimard.

Foucault, M. (1971). L'ordre du discours. Gallimard.

Foucault, M. (1972). The archaeology of knowledge (A. Sheridan, Trans.). Tavistock.

Foucault, M. (1977a, May 9). La grande colere des faits. Le nouvel observateur.

Foucault, M. (1977b). Discipline and punish:The birth of the prison (A. Sheridan, Trans.). Pantheon.

Foucault, M. (1980a). Intellectuals and power. In D. F. Bouchard (Ed.), Language, counter-memory, practice: Selected essays and interviews (D. F. Bouchard \& S. Simon, Trans.; pp. 205-217). Cornell University Press.

Foucault, M. (198ob). Nietzsche, genealogy, history. In D. F. Bouchard (Ed.), Language, counter-memory, practice: Selected essays and interviews (pp. 139-164). Cornell University Press.

Foucault, M. (1980c). Truth and power (C. Gordon, Trans.). In C. Gordon (Ed.), Power/ knowledge: Selected interviews and other writings 1972-1977 (pp. 109-133). Harvester Press.

Foucault, M. (1980d). Revolutionary action: "Until now". In D. F. Bouchard (Ed.), Language, counter-memory, practice: Selected essays and interviews (D. F. Bouchard \& S. Simon, Trans.; pp. 218-233). Cornell University Press.

Foucault, M. (1981). The order of discourse (I. McLeod, Trans.). In R. Young (Ed.), Untying the text: A post-structuralist reader (pp. 48-78). Routledge \& Kegan Paul.

Foucault, M. (1984). What is enlightenment? (C. Porter, Trans.). In P. Rabinow (Ed.), The Foucault reader (pp. 32-50). Pantheon.

Foucault, M. (1986). Death and the labyrinth: The world of Raymond Roussel (C. Ruas, Trans.). Introduction by J. Ashberry. Continuum.

Foucault, M. (1994a). Linguistique et sciences socials. In D. Defert \& F. Ewald (Eds.), Dits et écrits, 1954-1988 (4 Vols, Vol. 1, No. 70, pp. 821-842). Éditions Gallimard. 
Foucault, M. (1994b). La philosophie analytique de la politique. In D. Defert \& F. Ewald (Eds.) with J. Lagrange, Dits et écrits, 1954-1988 (4 Vols., Vol. 3, No. 232, pp. 534-551). Éditions Gallimard.

Foucault, M. (1997a). What our present is. In S. Lotringer \& L. Hochroth (Eds.), The politics of truth (pp. 147-168). Semiotext(e).

Foucault, M. (1997b). Subjectivity and truth. In S. Lotringer \& L. Hochroth (Eds.), The politics of truth (pp. 171-198). Semiotext(e).

Foucault, M. (2002a). Interview with Michel Foucault. In J. D. Faubion (Ed.), Essential works of Foucault, 1954-1984, vol. 3: Power (R. Hurley et al., Trans.; pp. 239-297). Penguin.

Foucault, M. (2002b). Question of method. In J. D. Faubion (Ed.), Essential works of Foucault, 1954-1984, vol. 3: Power (R. Hurley et al., Trans.; pp. 223-238). Penguin.

Foucault, M. (2002c). The subject and power. In J. D. Faubion (Ed.), Essential works of Foucault, 1954-1984, Vol. 3: Power (R. Hurley et al., Trans.; pp. 326-348). Penguin.

Foucault, M. (2002d). The risks of security. In J. D. Faubion (Ed.), Essential works of Foucault, 1954-1984, vol. 3: Power (R. Hurley et al., Trans.; pp. 365-381). Penguin.

Foucault, M. (2005). The hermeneutics of the subject: Lectures at the Collège de France 1981-1982 (G. Burchell, Trans.; F. Gross, Ed.). Palgrave Macmillan.

Gearhart, S. (1992). Irreconcilable differences: Kant, Hegel, and the "idea" of critical history. In M. Hays (Ed.), Critical conditions: Regarding the historical moment (pp. 56-81). University of Minnesota Press.

Glucksmann, A. (1975). De la violence: Entretien avec André Glucksmann. Actuel, 17, $54-76$.

Glucksmann, A. (1977). Les maîtres penseurs. Grasset.

Grumley, J. E. (1989). History and totality: Radical historicism from Hegel to Foucault. Routledge.

Gutting, G. (2011). Thinking the impossible: French philosophy since 1960. Oxford University Press.

Hacking, I. (1982). Representing and intervening: Introductory topics in the philosophy of natural science. Cambridge University Press.

Haraway, D. (1991). Simians, cyborgs, and women: The reinvention of nature. Routledge.

Hartmann, K. (1972). Hegel: A non-metaphysical view. In A. MacIntyre (Ed.), Hegel: A collection of critical essays (pp. 104-124). Anchor.

Hegel, G. W. F. (1948). The spirit of Christianity and its fate. In Early Theological Writings (T. M. Know, Trans.; pp. 182-301). University of Pennsylvania Press.

Houlgate, S. (2004). Hegel, Nietzsche and the criticism of metaphysics. Cambridge University Press.

Hutchings, K. (2003). International political theory: Rethinking ethics in a global era. Sage. 
Hyppolite, J. (1996). Introduction to Hegel's philosophy of history (B. Harris \& J. Bouchard Spurlock, Trans.). University Press of Florida.

Leibniz, G. W. (1968). The monadology (R. Latta, Trans.). Forgotten Books. (Original work published 1898$)$

Leibniz, G. W. (2009). Principles of nature and grace (R. Latta, Trans.). Cornell University Library. (Original work published 1898)

Maker, W. (1994). Philosophy without foundations: Rethinking Hegel. SUNY Press.

Nietzsche, F. (1997). On the uses and disadvantages of history for life. In D. Breazeale (Ed.), Untimely meditations (R. J. Hollingdale, Trans,; pp. 104-108). Cambridge University Press.

Olssen, M. (2003). Structuralism, post-structuralism, neo-liberalism: Assessing Foucault's legacy. Journal of Education Policy, 18(2), 189-202. https://doi.org/10.108o/o268093022000043047

Olssen, M. (2006a). Michel Foucault: Materialism and education. Paradigm.

Olssen, M. (2006b). Foucault and the imperatives of education: Critique and self-creation in a non-foundational world. Studies in Philosophy and Education, 25, 245-271. https://doi.org/10.1007/s11217-0o6-0013-o

Olssen, M. (2006c). Foucault, educational research and the issue of autonomy. In P. Smeyers, \& M. A. Peters (Eds.), Postfoundationalist themes in the philosophy of education (pp. 57-79). Blackwell.

Olssen, M. (2010). Discourse, complexity, life: Elaborating the possibilities of Foucault's materialist concept of discourse. In C. B. Grant (Ed.), Beyond universal pragmatics: Studies in the philosophy of communication (pp. 25-58). Peter Lang.

Olssen, M. (2016, March 28). Language, madness, and desire: On literature. Notre Dame Philosophical Reviews. https://ndpr.nd.edu/reviews/language-madness-anddesire-on-literature/

Olssen, M., Codd, J., \& O'Neill, A.-M. (2004). Education policy: Globalization, citizenship \& democracy. Sage.

Plant, R. (1973). Hegel. Allen \& Unwin.

Plotnitsky, A. (1996). Foreword. In J. Hyppolite (Ed.), Introduction to Hegel's philosophy of history (B. Harris \& J. Bouchard Spurlock, Trans.). University Press of Florida.

Rose, G. (1981). Hegel contra sociology. Athlone.

Rouse, J. (1996). Engaging science: How to understand its practices philosophically. Cornell University Press.

Sallis, J. (1995). Delimitations: Phenomenology and the end of metaphysics (2nd ed.). Indiana University Press.

Stark, W. (1943). The ideal foundations of economic thought. Kegan Paul.

Zamora, D., \& Behrent, M. C. (2016). Foucault and neoliberalism. Polity. 